\title{
DECISION SUPPORT SYSTEM BASED IN AHP METHOD TO SELECTION VENDORS OF CLINICAL LABORATORYS INPUTS
}

\author{
André Andrade Longaray \\ Federal University of Rio Grande - Brazil, Brazil \\ E-mail: longaray@yahoo.com.br \\ Anderson Picua Gonçalves \\ Federal University of Rio Grande - Brazil, Brazil \\ E-mail: anderpigo@gmail.com \\ Vilmar Gonçalves Tondolo \\ Federal University of Pelotas - UFPEL, Brazil \\ E-mail: vtondolo@gmail.com \\ Rosana Tondolo \\ Federal University of Pelotas - UFPEL, Brazil \\ E-mail: rosanatondolo@gmail.com \\ Catia Maria dos Santos Machado \\ Federal University of Rio Grande - FURG, Brazil \\ E-mail: catiamachado.furg@gmail.com
}

Submission: 11/01/2018

Revision: 11/06/2018 Accept: 12/14/2018

\section{ABSTRACT}

In a competitive marketing scenario, the purchasing area contributes significantly to the achievement of organizational goals. Its mission is to identify the competitive needs of products and services, becoming responsible for the timely delivery, costs optimization and quality. Within shopping, a correct selection of vendors is important for this to happen. From this perspective, the present study aims to develop a model that assists in the vendors' selection process. In order to achieve this goal, we conduct case study in a clinical analysis laboratory located in the city of Rio Grande, where the AHP (Analytic Hierarchy Process) was used as an intervention tool. The development process consisted in three stages. The first one aimed at structuring the model, in which the hierarchy of criteria was defined. In the second step, the judgments were carried out and the relative weights for each criterion and subcriterion were calculated. 
INDEPENDENT JOURNAL OF MANAGEMENT \& PRODUCTION (IJM\&P)

http://www.ijmp.jor.br

V. 10, n. 5, September-October 2019

ISSN: 2236-269X

DOI: 10.14807/ijmp.v10i5.896

Finally, the third step aimed at applying the model developed in a purchasing process. The model was tested in a selection process that involved the evaluation of three vendors of a laboratorial input, in order to identify which one met the demands of the organization. The result obtained with its use was considered satisfactory, this way, the model was approved by the manager who participated in the structuring process of the AHP hierarchy.

Keywords: AHP, vendors selection, clinical laboratory

\section{INTRODUCTION}

Supply logistics aims to make available, in a dynamic and integrated way, the material resources, equipment and information that contribute to the attainment of the goals of an organization (BALLOU, 2001). Insert in this scenario, the purchasing area plays a fundamental role in achieving the company's objectives, as its mission is to understand the competitive needs of products and services, becoming responsible for the timely delivery, costs, quality and other elements in the operations strategy (COLETTI; CASTALLANELLI; DIDONET, 2002). Alignment between strategy and purchasing management function is central to company's performance (RODRÍGUEZESCOBAR; GONZÁLEZ-BENITO, 2017).

In order to ensure that business processes occur efficiently, the tasks of identifying the best vendors for a new product or service are essential (GUARANIERI, 2015). The proper choice of a vendor can produce positive results in the supply system, while an inappropriate choice will certainly bring problems not only to a particular area of the company but also to other functions involved in this decision, directly impacting the company's profitability. The inappropriate selection of vendors may result to the strategic purposes of the organizations in the future need of replacement, which implies costs for the organization (BUSTAMENTE,;UARTE; ALMEIDA, 2010). Regarding supply chain as a role, vendors are one of the critical keys aspects of company's performance (PARK; OK; HA, 2018).

In this sense, the search for tools that facilitate the decision making process has become frequent. Considering the nature that involves multiple criteria in the selection of vendors, it is necessary to include an approach to aggregate them adequately, and it is important to emphasize that there are several methods used for 
INDEPENDENT JOURNAL OF MANAGEMENT \& PRODUCTION (IJM\&P)

http://Www.ijmp.jor.br

V. 10, n. 5, September-October 2019

ISSN: 2236-269X

DOI: 10.14807/ijmp.v10i5.896

this purpose. Their choice basically depends on the decision objectives, the types of criteria to be used and the decision maker's rationality (GUARANIERI, 2015).

The problem of vendors selection has been widely discussed in the Brazilian scientific literature (TRAMARICO et al., 2012), because the supplier evaluation and selection process depends on several factors. The existing studies on the subject present several methodologies and decision support criteria that can be considered in the evaluation and selection of companies that supply the most varied products and services.

In this context, a systematic literature review was carried out using the bibliometry technique, with which a sample of 85 articles were collected, from the online databases, Scielo and Academic Google. With the analysis of these 85 articles, it was possible to identify what has been published regarding vendors selection, as well as on multicriteria decision support methods. This study also made it possible to identify research gaps regarding the application of the multicriteria decision support model in several areas, such as selection of vendors of butchery equipment, uniforms, construction materials, and clinical laboratory inputs. Base on that preliminary study emerged the following research question: How to develop a model that assists in the vendors' selection process to the Clinical Analysis context?

From this perspective, the present study aims to develop a model that assists in the vendors' selection process. In order to achieve this goal, we conducted a qualitative and quantitative case study using interviews and questionnaires as data collection instruments. The multicriteria AHP method was the main procedure of data analysis. Our study was conducted in a laboratory located in the city of Rio Grande, which is small in size, with 17 employees and serves about 3000 clients per month.

This article is divided into six sections. Having established the introduction, section 2 presents an overview of the problem of vendor's selection. Section 3 discusses the AHP, which is the multicriteria method used in the study. Section 4 presents the methodology adopted in the study. Section 5 details the steps proceeded in the case study. Finally, section 6 presents the concluding remarks, highlighting some research opportunities on the topic.

\section{SELECTION OF VENDORS}


INDEPENDENT JOURNAL OF MANAGEMENT \& PRODUCTION (IJM\&P)

http://Www.ijmp.jor.br

V. 10, n. 5, September-October 2019

ISSN: 2236-269X

DOI: 10.14807/ijmp.v10i5.896

According to Gonçalo and Alencar (2011), vendors selection is a process in which vendors are inspected, evaluated, and chosen to eventually become part of an organization's supply chain .The purpose of this selection is to identify the vendors with the greatest potential to meet the needs of the organization, being this vendor adapted to the company's strategy. The growing impact of the vendor on the performance of organizations has reinforced the need to hire well-qualified companies who are committed with the contractor's goals. As a consequence, organizations have become increasingly selective, incorporating new criteria into the selection process and intensifying vendor's monitoring (VIANA; ALENCAR, 2010).

According to Aires, Silveira Neto, Salgado, Araujo and Colombo (2013), the current marketing environment is competitive, characterized by low profit margins, high expectations for quality products and services, and short deadlines. They also point out that for these objectives to be achieved it is necessary for companies to consider all the dimensions that involve their supply chain, from product delivery, quality and flexibility, to response time, as they are forced to obtain advantage of every opportunity to optimize their business processes.

The steady increase in vendor participation in the overall performance of the organization is largely a consequence of the recent emphasis on building partnership relationships. By focusing on their business purpose, passing on all other non-core business activities to third parties, organizations become more and more dependent on their vendors' performance. In this context, it is important to promote the coordination of operations between organizations, which requires the construction of close, reliable and long-lasting relationships (VIANA; ALENCAR, 2012).

Gonçalo and Alencar (2011) point out that there is a trend in maintaining longterm partnerships between companies and their vendors and the use of less vendors and more reliable ones. The authors also show that the criteria most considered by decision-makers to evaluate and select vendors no longer have the price factor as the main criterion, according to the authors' search, in order of occurrence: quality, delivery, price cost, manufacturing capacity, service, management, technology, research and development, finance, flexibility, reputation, relationship, risk and safety, and the environment. 
INDEPENDENT JOURNAL OF MANAGEMENT \& PRODUCTION (IJM\&P)

http://www.ijmp.jor.br

V. 10, n. 5, September-October 2019

ISSN: 2236-269X

DOI: 10.14807/ijmp.v10i5.896

Denicol and Cassel (2013) argue that the buyer-vendor relationship based solely on cost is no longer acceptable. They also say that increasing the importance of decisions for vendor's selection has led organizations to rethink their procurement and evaluation strategies in order to reach the most appropriate vendor to meet their demands. In this context, it is understood that the task of evaluating and selecting vendors involves multiple criteria, which makes it necessary to use methods to aggregate them adequately.

\section{AHP MULTI-CRITERIA METHOD}

Multicriteria Decision Support (MCDS) approach to operational research is characterized as a set of methods used to support organizations to make fitting decisions even under the influence of numerous criteria (SOUZA; CARMO, 2015). According to Alencar, Almeida and Mota (2007), multicriteria decision support modeling does not aim to find a solution that is a single truth represented by the selected action, but to support the decision process so that the satisfactory decision is made according to the criteria of the decision-makers.

Analyzing the existing literature on the subject, we observe the use of several multicriteria methodologies. Among the methods cited in the analyzed articles are those of the ELECTRE family (Elimination and Choice Translating Reality), as well as those of the PROMETHEE family (Preference Ranking Method for Enrichment Evaluation), as well as methods such as AHP (Analytic Hierarchy Process), ANP (Analytic Network Process), and TOPSIS (Technique for Order Preference by Similarity to Ideal Solution) (LONGARAY; BUCCO, 2014).

Among these methods, AHP stands out because it has wide applicability, robustness and flexibility (LONGARAY; BUCCO, 2014; LONGARAY; ENSSLIN, 2014). Thus, the use of this method is justified, since the vendors selection process, which is the subject of this study, is an example of a complex decision, since it takes into account several criteria, which makes up the relationship between customers and their vendors.

The Analytic Hierarchy Process (AHP), proposed by Saaty (2008), is a comparison of pairs, methodology that results in the breaking of a complex problem and then combining the solutions. It has been widely recognized that AHP analysis is one of the best methodologies to prioritize various indicators. In addition, the AHP 
INDEPENDENT JOURNAL OF MANAGEMENT \& PRODUCTION (IJM\&P)

http://www.ijmp.jor.br

V. 10, n. 5, September-October 2019

ISSN: 2236-269X

DOI: 10.14807/ijmp.v10i5.896

approach needs only a small number of respondents with experience and knowledge (COSTA; RAMOS, 2015).

The basic principle of the AHP method lies in the analysis of several alternatives of different criteria (COSTA; RAMOS, 2015). Thus, the AHP model is constructed in the form of a descending hierarchical structure, from a global objective to criteria, subcriteria and alternatives, at successive levels (SAATY, 2008 ). As can be seen in figure 1 , the overall objective is put on the first level, which is decomposed into secondary objectives, and these are succeeded by decision alternatives, in a number of levels and criteria that represent the problem as completely as possible without which, however, implies the loss of sensitivity to changes in the elements of the model (LONGARAY; BUCCO, 2014).

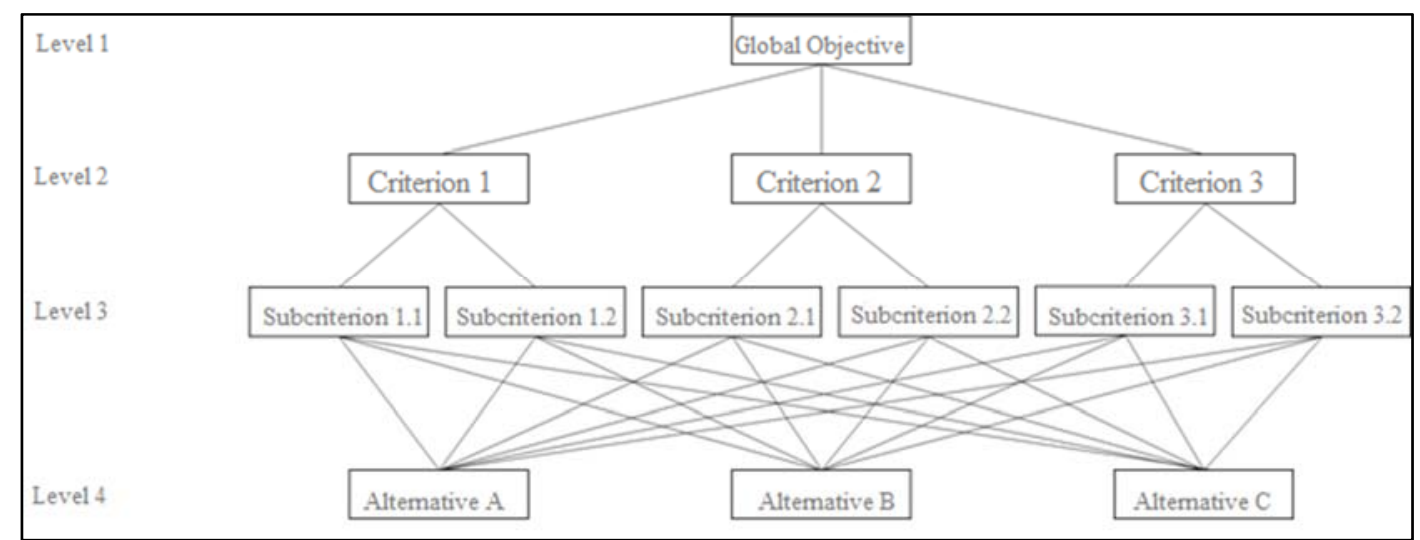

Figure 1: AHP Hierarch

Source: Adapted from Major and Belderrain (2007)

From the construction of the hierarchical structure, the stages of judgment and synthesis of the priorities of each criterion and subcritera are followed. The criteria judged is made by means of the peer-to-peer comparison, using a scale developed by Saaty (2008). Such a scale is shown in Table 1.

Table 1: Saaty fundamental scale

\begin{tabular}{|c|l|}
\hline $\begin{array}{c}\text { Intensity of importance on } \\
\text { an absolute scale }\end{array}$ & \multicolumn{1}{c|}{ Definition } \\
\hline 1 & Equal importance \\
\hline 3 & Moderate importance of one over another \\
\hline 5 & Essential or strong importance \\
\hline 7 & Very strong importance \\
\hline 9 & Extreme Importance \\
\hline $2,4,6,8$ & Intermediate values between two adjacent judgments \\
\hline Reciprocal & $\begin{array}{l}\text { If activity } i \text { has one of the numbers above when } \\
\text { compared to activity } j \text {, then activity } j \text { has the reciprocal } \\
\text { value when compared to } i\end{array}$ \\
\hline
\end{tabular}

Source: Adapted from Saaty (2008) 
INDEPENDENT JOURNAL OF MANAGEMENT \& PRODUCTION (IJM\&P)

http://Www.ijmp.jor.br

V. 10, n. 5, September-October 2019

ISSN: 2236-269X

DOI: 10.14807/ijmp.v10i5.896

Based on comparative judgments, a positive array of options is derived from these criteria. A structure is obtained later, with a vector of priorities. The same procedure is applied for the alternatives considered for each criterion. Then, the weights of the criteria are applied for the considered alternatives and, finally, the corresponding totals for each alternative are calculated (COSTA; RAMOS, 2015).

\section{METHODOLOGY}

This section describes the methodological procedures adopted in the development of this work as to its purpose, its nature, the source of data collection, the research logic, the methodological approach and the intervention instrument used. In general, this research has a nature practical driven.

As to its purpose, the present work is characterized as an exploratory study. According to Triviños (1995), the exploratory studies allow the researcher to increase his experience around certain problems. Based on a hypothesis, the researcher deepens his study within the limits of a specific reality, seeking antecedents and greater knowledge. This perspective is in line with the general and specific objectives of this research, aimed at the construction of a customized vendor selection model for a clinical analysis laboratory, in order to identify, operationalize and measure actions that meet the needs of the organization.

As far as its nature is concerned, this research can be classified as a case study. According to Yin (2001), the application of the case study enables the transformation of goals into actions that are feasible and consistent with the reality in which the analyzed organization is inserted .It takes into consideration, mainly the comprehension, as a whole, of the investigated subject, leading to the emergence and discovery of relations that otherwise would not be established.

The case described in this study was developed in a laboratory of clinical analyzes, located in the city of Rio Grande - RS. In this laboratory work 17 employees, distributed in the areas of management, billing, reception, collection and analysis of samples. The company watches monthly on average 3000 clients, those coming from the private service and from agreements that the company maintains with public and private agencies.

The data source is characterized as being of primary nature. The necessary information for the development of the study was obtained from the laboratory 
manager, who participated in all stages of the process. In this process, the data were obtained through semi-structured interviews and a questionnaire.

As for the research logic, it can be inferred that it is mixed. In the structuring phase, logic is inductive, because at this stage in which the elements of evaluation are determined, it is not based on principles but on facts resulting from observations and insertion in reality (ROESCH, 2010). Already in the evaluation stage, the logic is deductive, because, from the constructed model, we seek to establish particular conclusions (TRIVIÑOS, 1995). In the recommendations phase, the logic is predominantly inductive, since the analyzes are made from the understanding acquired throughout the development of the model.

The methodological approach used in this research is characterized as qualitative-quantitative (ROESCH, 2010). The study assumes the qualitative profile in the structuring phase, based on an intervention process that promotes reflection in search of identification, representation and determination of the primary evaluation elements and their interrelationships in the construction of ordinal scales. It can be characterized as quantitative in the evaluation phase, when the construction of the multicriteria mathematical model occurs, through the transformation of the ordinal scales into cardinal scales, the determination of the compensation rates between criteria and the identification of the performance profile of the actions.

The intervention instrument selected for the development of the vendor's selection model, and main procedure of analysis is the multicriteria AHP method. The choice of this methodology of support to the decision is due to its ability to provide conditions for identification, operationalization and measurement of the actions that represent the perception of the laboratory manager, as well as the possibility of selecting a vendor that meets the demands of the company.

\section{DEVELOPMENT OF THE MODEL}

The AHP method is applied in three steps: structuring the model, realizing the judgments and summarizing the priorities, and finally, a purchasing process using the developed model.

\subsection{Structuring the model}


INDEPENDENT JOURNAL OF MANAGEMENT \& PRODUCTION (IJM\&P)

http://Www.ijmp.jor.br

V. 10, n. 5, September-October 2019

ISSN: 2236-269X

DOI: 10.14807/ijmp.v10i5.896

The unit of analysis of this research is a clinical analysis laboratory, where varieties of products, such as chemical solutions, laboratory glassware, plastic materials, stationery, etc are purchased throughout a financial year.

Due to the amount of resources spent in the industry and the great variation in the quality of the products supplied, it is important that these vendors can be selected in an efficient manner, thus enabling the supplied inputs to have quality, competitive prices, as well as delivery guaranteed within the specified period and under the conditions promised.

At the Company, decisions about vendor selection are based on buyers' experience rather than on formally discussed and pre-established criteria. It is proposed, therefore, the construction of the AHP method, a rational and structured tool, capable of assisting the decision maker in choosing the company that meets the needs of the laboratory.

To do so, initially, information was collected for the process of structuring the AHP hierarchy, these were obtained through interviews with the manager responsible for decision making in the organization. Having in hand the necessary data, the hierarchy was constructed, this one is presented in figure 2.

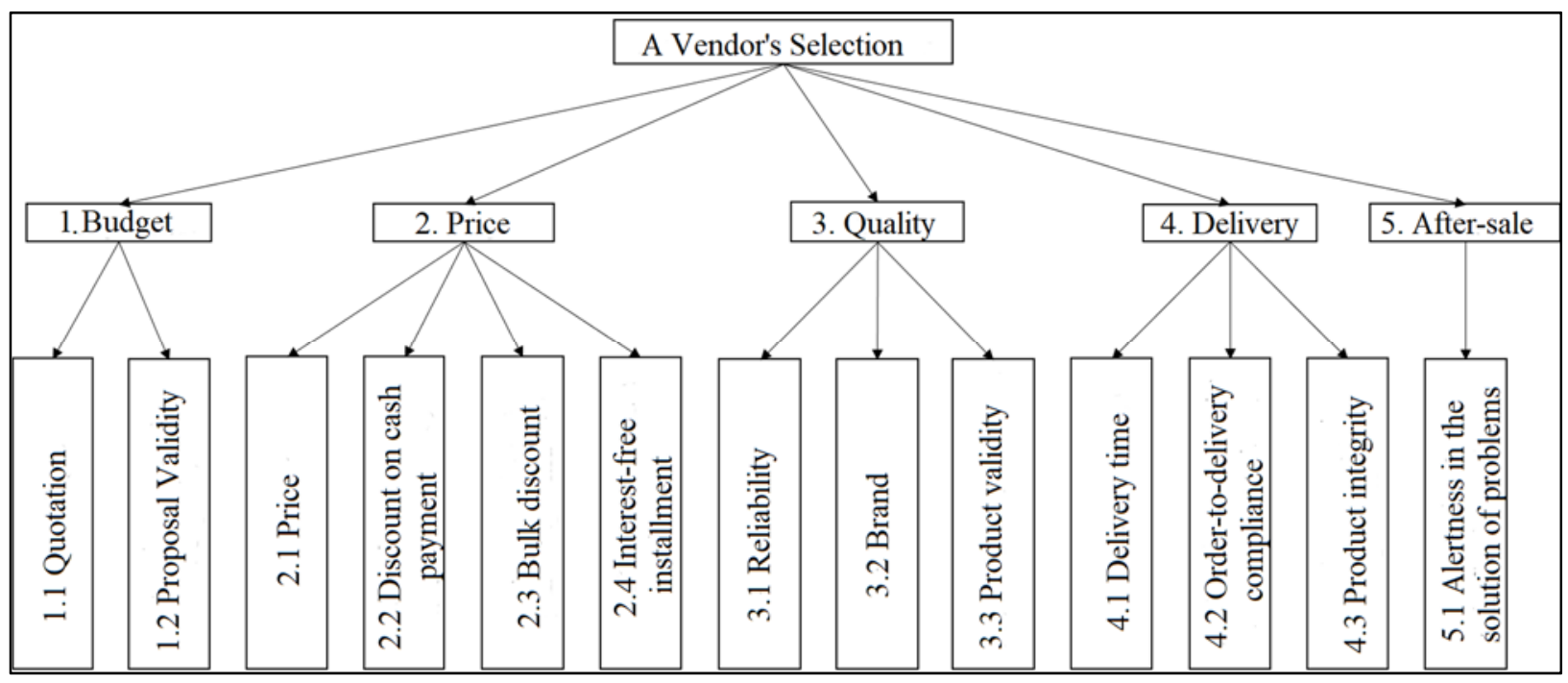

Figure 2: AHP Hierarchy

It is identified in Figure 2 that the first level is intended for the general purpose of the model, in this case the selection of a vendor. In the next level (Level 2), the criteria "Budget", "Price", "Quality", "Delivery" and "Post-sale" are located, which aim to contribute, each with its relative weight, to its achievement. Finally, located at the 
INDEPENDENT JOURNAL OF MANAGEMENT \& PRODUCTION (IJM\&P)

http://Www.ijmp.jor.br

V. 10, n. 5, September-October 2019

ISSN: 2236-269X

DOI: 10.14807/ijmp.v10i5.896

third level, are the quantifiable criteria, defined here as subcriteria, that serve as a reference for directly evaluating decision alternatives.

With regard to the "Budget" criterion, the subcriterion "Quotation", which corresponds to the effort required to obtain the information necessary to evaluate the vendor, and the "Proposal Validity", which is intended to define a validity period for the information obtained with the quotation.

In order to evaluate the "Price" criterion, the subcriteria "Price" - unit price of the product, "Discount on payment sighted" - discount percentage offered by the vendor, if payment is made on the same day of delivery, "Discount on large quantities " percentage of discount offered by the supplier when a significant quantity of products are purchased, and "Interest free installments" - maximum number of monthly installments, without occurrence of additional collection.

Next, it was selected, in order to evaluate the "Quality" criterion, "Reliability" takes into account the history of the product, if it has already presented a problem, the "Brand" of the product, since certain brands imply loss of the equipment warranty, and the "Product Validity" that determines the time the laboratory will have to use the product, and is also decisive in the case of a large amount of purchases.

As for the "Delivery" criterion, if "Delivery time" has been defined - the time that the vendor took to deliver the product after the order has been made, the "Conformity between order and delivery" - what was delivered is in accordance with the combined, and "Product Integrity", which evaluates whether any product has been damaged or lost during delivery.

Lastly, there is the "After-Sale" criterion, which was quantified by means of "Problem Solving Readiness", in order to evaluate the vendor's response time in the event of an invoice or ticket problem and product integrity during the delivery of the same.

Defining the criteria and subcriteria in a hierarchical structure, the next step of the AHP method is started: the execution of judgments and the calculation of relative weights.

\subsection{Carrying out the judgments and calculating the relative weights}


INDEPENDENT JOURNAL OF MANAGEMENT \& PRODUCTION (IJM\&P)

http://www.ijmp.jor.br

V. 10, n. 5, September-October 2019

ISSN: 2236-269X

DOI: 10.14807/ijmp.v10i5.896

The execution of the judgments occurs through paired comparisons between the criteria of the same level, thus allowing to evaluate the relative preferences between each element of decision. The comparison is made using the AHP Pair Comparison Scale, shown in Table 1.

In order to facilitate the process of judgment, a questionnaire ${ }^{i}$ was constructed and presented to the interviewee. The following is an example of the peer questionnaire for Level 2 and Level 3 components. In the first, all the pairs of criteria are compared, and in the second, all pairs of subcriteria are compared, which in the case of the following example is the "Budget".

Level 2: Criteria

\begin{tabular}{|l|l|l|l|l|l|l|l|l|l|l|l|l|l|l|l|l|l|}
\cline { 2 - 13 } \multicolumn{1}{c|}{ How important is "budget" when compared to "price"? } \\
\hline Q1 & 9 & 8 & 7 & 6 & 5 & 4 & 3 & 2 & 1 & 2 & 3 & 4 & 5 & 6 & 7 & 8 & 9 \\
\hline
\end{tabular}

\begin{tabular}{|l|c|c|c|c|c|c|c|c|c|c|c|c|c|c|c|c|c|}
\cline { 2 - 14 } \multicolumn{1}{c|}{ How important is "budget" when compared to "quality"? } \\
\hline Q2 & 9 & 8 & 7 & 6 & 5 & 4 & 3 & 2 & 1 & 2 & 3 & 4 & 5 & 6 & 7 & 8 & 9 \\
\hline
\end{tabular}

\begin{tabular}{|l|c|c|c|c|c|c|c|c|c|c|c|c|c|c|c|c|c|}
\cline { 2 - 14 } \multicolumn{1}{c|}{ How important is the "budget" when compared to "delivery"? } \\
\hline Q3 & 9 & 8 & 7 & 6 & 5 & 4 & 3 & 2 & 1 & 2 & 3 & 4 & 5 & 6 & 7 & 8 & 9 \\
\hline
\end{tabular}

\begin{tabular}{|c|c|c|c|c|c|c|c|c|c|c|c|c|c|c|c|c|c|}
\cline { 2 - 13 } \multicolumn{1}{c|}{ How important is the "budget" when compared to "after-sale"? } \\
\hline Q4 & 9 & 8 & 7 & 6 & 5 & 4 & 3 & 2 & 1 & 2 & 3 & 4 & 5 & 6 & 7 & 8 & 9 \\
\hline
\end{tabular}

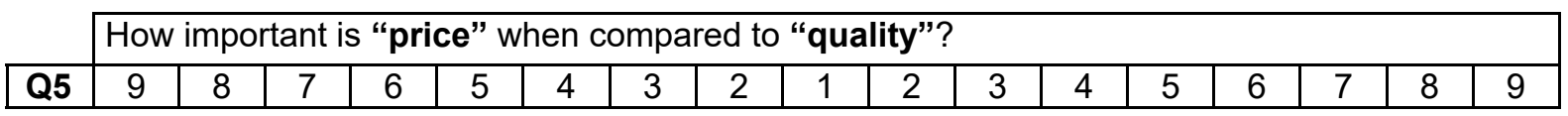

\begin{tabular}{|c|c|c|c|c|c|c|c|c|c|c|c|c|c|c|c|c|c|}
\cline { 2 - 14 } \multicolumn{1}{c|}{ How important is "price" when compared to "delivery"? } \\
\hline Q6 & 9 & 8 & 7 & 6 & 5 & 4 & 3 & 2 & 1 & 2 & 3 & 4 & 5 & 6 & 7 & 8 & 9 \\
\hline
\end{tabular}

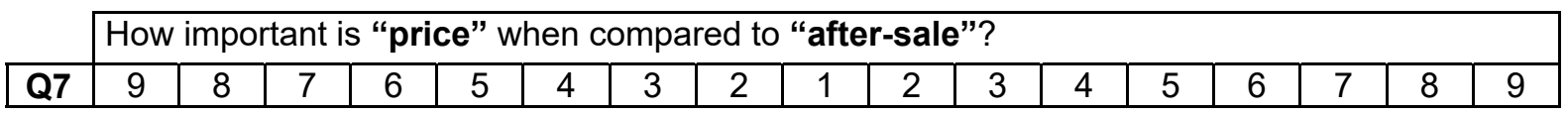

\begin{tabular}{|l|c|c|c|c|c|c|c|c|c|c|c|c|c|c|c|c|c|}
\cline { 2 - 14 } \multicolumn{1}{c|}{ How important is "quality" when compared to "delivery"? } \\
\hline Q8 & 9 & 8 & 7 & 6 & 5 & 4 & 3 & 2 & 1 & 2 & 3 & 4 & 5 & 6 & 7 & 8 & 9 \\
\hline
\end{tabular}

\begin{tabular}{|l|c|c|c|c|c|c|c|c|c|c|c|c|c|c|c|c|c|}
\cline { 2 - 14 } \multicolumn{1}{c|}{ How important is "quality" when compared to "after-sales"? } \\
\hline Q9 & 9 & 8 & 7 & 6 & 5 & 4 & 3 & 2 & 1 & 2 & 3 & 4 & 5 & 6 & 7 & 8 & 9 \\
\hline
\end{tabular}

\begin{tabular}{|l|l|l|l|l|l|l|l|l|l|l|l|l|l|l|l|l|}
\cline { 2 - 14 } \multicolumn{1}{c|}{} & How important is "delivery" when compared to "after-sale"? \\
\hline Q10 & 9 & 8 & 7 & 6 & 5 & 4 & 3 & 2 & 1 & 2 & 3 & 4 & 5 & 6 & 7 & 8 \\
\hline
\end{tabular}

Level 3: Budget Components

\begin{tabular}{|l|l|l|l|l|l|l|l|l|l|l|l|l|l|l|l|l|l|}
\cline { 2 - 14 } \multicolumn{1}{c|}{ How important is "quotation" when compared to "proposal validity"? } \\
\hline Q11 & 9 & 8 & 7 & 6 & 5 & 4 & 3 & 2 & 1 & 2 & 3 & 4 & 5 & 6 & 7 & 8 & 9 \\
\hline
\end{tabular}


INDEPENDENT JOURNAL OF MANAGEMENT \& PRODUCTION (IJM\&P)

http://Www.ijmp.jor.br

V. 10, n. 5, September-October 2019

ISSN: 2236-269X

DOI: 10.14807/ijmp.v10i5.896

To respond to the questionnaire the respondent received the following guidelines: and the first attribute is more important than the second, tick your answer in one of the boxes to the left of the option "1", depending on your preference. If the second attribute is more important than the first, choose your answer in the boxes to the right of option "1".

After the comparisons were made and the preferences defined, the values of this scale were introduced into an array, which has as reference the generic reciprocal matrix shown in Figure 3.Thus, the results of the paired comparisons of level 2 are described in Table 1.

$$
A=\left|\begin{array}{cccc}
1 & a_{12} & \sqcup & a_{1 n} \\
1 / a_{12} & 1 & \ldots & a_{2 n} \\
\square & \square & & \square \\
1 / a_{1 n} & 1 / a_{2 n} & \cdots & 1
\end{array}\right|
$$

Figure 3: Generic reciprocal matrix

Source: Longaray and Bucco (2014)

Table 1: Results of paired comparisons of level 2

\begin{tabular}{cccccc}
\hline CRITERION & Budget & Price & Quality & Delivery & $\begin{array}{c}\text { After- } \\
\text { sales }\end{array}$ \\
\hline Budget & 1.00 & 0.13 & 0.13 & 0.50 & 1.00 \\
\hline Price & 8.00 & 1.00 & 1.00 & 5.00 & 6.00 \\
\hline Quality & 8.00 & 1.00 & 1.00 & 6.00 & 6.00 \\
\hline Delivery & 2.00 & 0.20 & 0.17 & 1.00 & 2.00 \\
\hline After-sales & 1.00 & 0.17 & 0.17 & 0.50 & 1.00 \\
\hline & & Source: Prepared by the authors & &
\end{tabular}

As can be seen in Table 2, the "Price" and "Quality" criteria have strong or extremely preferential importance over the "Budget" criterion, and so on. Following this line of reasoning, matched comparison matrices for level 3 were constructed .These are presented in Tables 2, 3, 4 and 5.

Table 2: Result of the paired comparisons of the sub-criteria of the "Budget"

\begin{tabular}{ccc}
\hline Subcriteria of the Budget & price & Validity of the proposal \\
\hline price & 1.00 & 1.00 \\
\hline Validity of the proposal & 1.00 & 1.00 \\
\hline
\end{tabular}

Table 3: Results of the paired comparisons of the sub-criteria of the "Price"

\begin{tabular}{ccccc}
\hline $\begin{array}{c}\text { Subcriteria of the } \\
\text { Price }\end{array}$ & Price & $\begin{array}{c}\text { Discount on cash } \\
\text { payment }\end{array}$ & $\begin{array}{c}\text { Discount on large } \\
\text { quantities }\end{array}$ & $\begin{array}{c}\text { Interest free } \\
\text { parcelling }\end{array}$ \\
\hline Price & 1.00 & 4.00 & 4.00 & 5.00 \\
\hline $\begin{array}{c}\text { Discount on cash } \\
\text { payment }\end{array}$ & 0.25 & 1.00 & 1.00 & 6.00 \\
\hline $\begin{array}{c}\text { Discount on } \\
\text { large quantities }\end{array}$ & 0.25 & 1.00 & 1.00 & 6.00 \\
\hline
\end{tabular}


INDEPENDENT JOURNAL OF MANAGEMENT \& PRODUCTION (IJM\&P)

http://www.ijmp.jor.br

V. 10, n. 5, September-October 2019

ISSN: 2236-269X

DOI: 10.14807/ijmp.v10i5.896

\begin{tabular}{ccccc}
\hline $\begin{array}{c}\text { Interest free } \\
\text { parcelling }\end{array}$ & 0.20 & 0.17 & 0.17 & 1.00 \\
\hline
\end{tabular}

Table 4: Results of the paired comparisons of the sub-criteria of "Quality"

\begin{tabular}{|c|c|c|c|}
\hline Subcriteria of Quality & Reliability & Brand & Product validity \\
\hline Reliability & 1.00 & 3.00 & 4.00 \\
\hline Brand & 0.33 & 1.00 & 2.00 \\
\hline Product validity & 0.25 & 0.50 & 1.00 \\
\hline
\end{tabular}

Table 5: Result of the matched comparisons of the sub-criteria of the "Delivery"

\begin{tabular}{cccc}
\hline $\begin{array}{c}\text { Subcriteria of the } \\
\text { Delivery }\end{array}$ & Deadline & $\begin{array}{c}\text { Order-to-delivery } \\
\text { compliance }\end{array}$ & Product Integrity \\
\hline Deadline & 1.00 & 1.00 & 2.00 \\
\hline $\begin{array}{c}\text { Order-to-delivery } \\
\text { compliance }\end{array}$ & 1.00 & 1.00 & 2.00 \\
\hline Product Integrity & 0.50 & 0.50 & 1.00 \\
\hline
\end{tabular}

It is worth mentioning that because the criterion "After-sale" has only one subcriterion, there is no possibility of building a matrix. In this case the "Alertness in the solution of problems" has all representative of the criterion.

Constructed all matrices, the calculation of relative weights was started, which could be conducted using Microsoft Excel .For calculation purposes, three steps are suggested (SAATY, 2008; COSTA; RAMOS, 2015).

1. The results of the paired comparisons are presented in Tables 1, 2, 3, 4 and 5 to insert the data in Excel, where the construction of matrices of binary comparisons is performed for each level of the hierarchical structure.

2. Summary of priorities:

2.1. Add each column of the matrix;

2.2. Divide each element of the matrix by the sum of the corresponding column, obtaining a new standardized matrix;

2.3. The average of each row of the standardized matrix (sum and division by $n$ variables considered) is calculated, obtaining the column vector of "W" (relative weight). The sum of the vector must be equal to 1 ;

3. Matrix consistency check (MC):

3.1. Multiply the sum of each column of the original matrix (step 2.1) by the vector of "W" (step 2.3), obtaining a new vector (measure of consistency); 
INDEPENDENT JOURNAL OF MANAGEMENT \& PRODUCTION (IJM\&P)

http://Www.ijmp.jor.br

V. 10, n. 5, September-October 2019

ISSN: 2236-269X

DOI: 10.14807/ijmp.v10i5.896

3.2. If the matrix is consistent, the $s$ vectors calculated in step 3.1 will have preference values equal to 1 .

Tables 6 and 7 below present the matrix of level 2 with the criteria and a matrix of level 3, which is represented by the subcriteria of the "Budget". In them are contained the results regarding relative weights and the measure of consistency (MC) of each criterion and subcriterion.

Table 6: Components of Level 2

\begin{tabular}{cccccccc}
\hline CRITERION & Budget & Price & Quality & Delivery & After-sales & W & MC \\
\hline Budget & 0.0500 & 0.0502 & 0.0508 & 0.0385 & 0.0625 & $\mathbf{5 . 0 4 \%}$ & 1,0079 \\
\hline Price & 0,4000 & 0,4013 & 0,4068 & 0.3846 & 0,3750 & $\mathbf{3 9 . 3 5 \%}$ & 0.9806 \\
\hline Quality & 0,4000 & 0,4013 & 0,4068 & 0.4615 & 0,3750 & $\mathbf{4 0 . 8 9 \%}$ & 1,0053 \\
\hline Delivery & 0.1000 & 0.0803 & 0.0678 & 0.0769 & 0.1250 & $\mathbf{9 . 0 0 \%}$ & 1,1700 \\
\hline After-sales & 0.0500 & 0.0669 & 0.0678 & 0.0385 & 0.0625 & $\mathbf{5 . 7 1 \%}$ & 0.9141 \\
\hline Sum & 1 & 1 & 1 & 1 & 1 & $\mathbf{1 0 0} \%$ & \\
\hline \multicolumn{7}{c}{ Source: Prepared by the authors }
\end{tabular}

Table 7: Components of the "Budget"

\begin{tabular}{ccccc}
\hline Budget Criteria & price & $\begin{array}{c}\text { Validity of the } \\
\text { proposal }\end{array}$ & W & MC \\
\hline Price & 0.5000 & 0.5000 & $\mathbf{5 0 . 0 0 \%}$ & 1 \\
\hline $\begin{array}{c}\text { Validity of the } \\
\text { proposal }\end{array}$ & 0.5000 & 0.5000 & $\mathbf{5 0 . 0 0 \%}$ & 1 \\
\hline Sum & 1 & 1 & $\mathbf{1 0 0 \%}$ & \\
\hline
\end{tabular}

Source: Prepared by the authors

After applying the same process to all matrices, we were able to illustrate the final results using the original hierarchical structure, as shown in Figure 4.

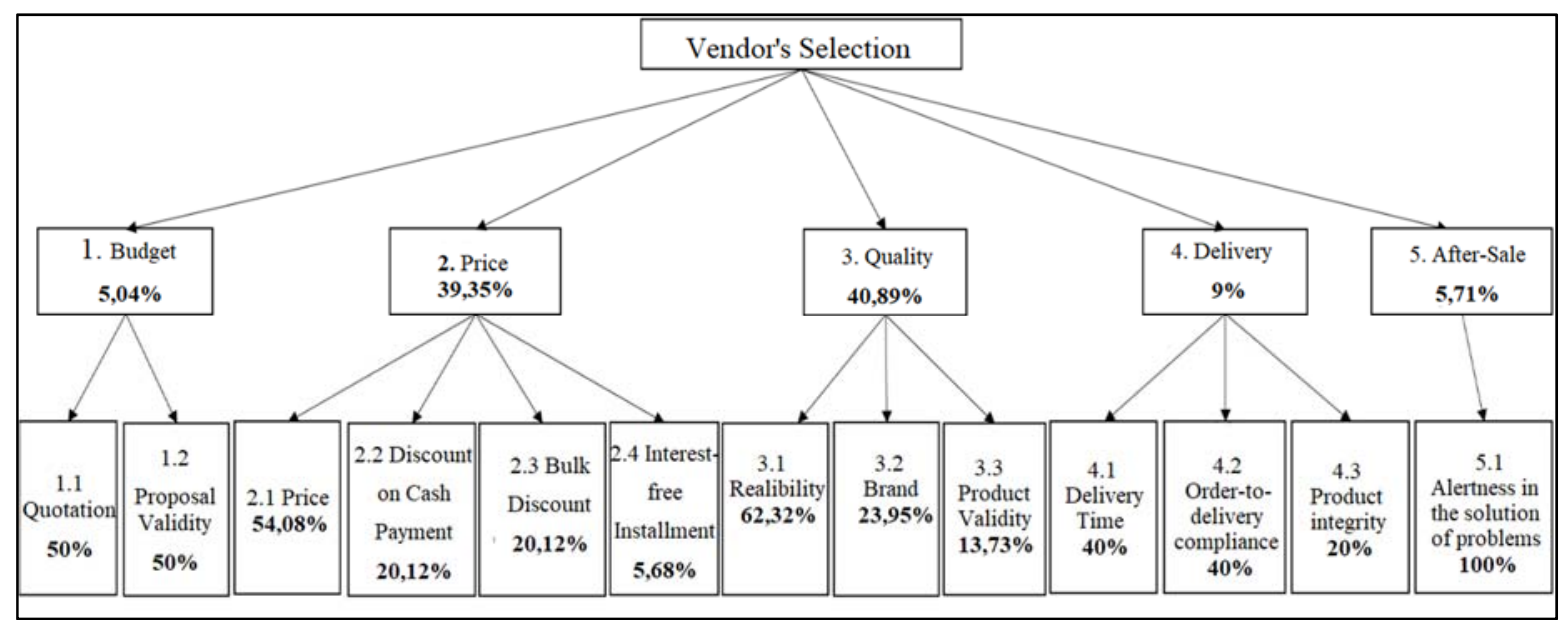

Figure 4: Percentage of relative weight for criteria and subcriteria

Once all the calculations have been made, the "Price" and the "Quality" are the most important criteria in the whole process, representing $39.35 \%$ and $40.89 \%$, 
INDEPENDENT JOURNAL OF MANAGEMENT \& PRODUCTION (IJM\&P)

http://www.ijmp.jor.br

V. 10, n. 5, September-October 2019

ISSN: 2236-269X

DOI: 10.14807/ijmp.v10i5.896

respectively. It could also be found that among the subcriteria of quality, which is the most important, the "Reliability" of the product represents $62.32 \%$ of the criterion.

\subsection{Purchase Simulation}

Taking possession of the synthesis of the model and the decision structure, the simulation of the purchase of a laboratory input was elaborated. This simulation was made with three vendors that currently participate in the quotation processes carried out in the laboratory. The evaluation process was based on the assignment of a grade in the scale of 1 to 5 for each subcriterion described in the hierarchical structure. Tables 8, 9 and 10 present the scores attributed to each subcriterion for the three vendors evaluated.

Table 8: Assignment of the note to vendor $A$

\begin{tabular}{ccl}
\hline Criterion & Note & \multicolumn{1}{c}{ Note } \\
\hline 1.1 & 4 & You had to get in contact twice to get all the information you need. \\
\hline 1.2 & 4 & A proposal valid for 17 days was submitted. \\
\hline 2.1 & 4 & The unit price was $\mathrm{R}$ \$ 750.50. \\
\hline 2.2 & 2 & Offered $3 \%$ discount for the cash payment. \\
\hline 2.3 & 2 & Offered $2 \%$ discount for purchase of 15 units or more. \\
\hline 2.4 & 3 & Portion up to 2 X without interest charges. \\
\hline 3.1 & 5 & The product offered has no history of problems. \\
\hline 3.2 & 4 & The brand is generic, which causes you to lose the equipment warranty. \\
\hline 3.3 & 3 & The product is valid for 160 days. \\
\hline 4.1 & 4 & Delivery was made in 6 business days. \\
\hline 4.2 & 4 & The price reported in the invoice was not the same as the combined price. \\
\hline 4.3 & 5 & No product has been damaged or lost. \\
\hline 5.1 & 2 & The correction of the invoice was carried out in 4 working days.
\end{tabular}

Source: Prepared by the authors

Table 9: Assignment of the note to vendor $B$

\begin{tabular}{ccl}
\hline Criterion & Note & \multicolumn{1}{c}{ Note } \\
\hline 1.1 & 4 & You had to get in contact twice to get all the information you need. \\
\hline 1.2 & 3 & A proposal valid for 12 days was submitted. \\
\hline 2.1 & 4 & The unit price of the product was $\mathrm{R} \$ 751.00$. \\
\hline 2.2 & 2 & Offered $3 \%$ discount for the cash payment. \\
\hline 2.3 & 2 & Offered $3 \%$ discount for purchase of 15 units or more. \\
\hline 2.4 & 3 & Portion up to 3X without additional charge. \\
\hline 3.1 & 4 & $\begin{array}{l}\text { The product has already presented a problem once, interrupting the } \\
\text { operation of the equipment for a period of 2 days. }\end{array}$ \\
\hline 3.2 & 4 & $\begin{array}{l}\text { The product is generic, which results in the loss of the equipment } \\
\text { warranty. }\end{array}$ \\
\hline 3.3 & 4 & The product delivered is still valid for 218 days. \\
\hline
\end{tabular}


INDEPENDENT JOURNAL OF MANAGEMENT \& PRODUCTION (IJM\&P)

http://www.ijmp.jor.br

V. 10, n. 5, September-October 2019

ISSN: 2236-269X

DOI: 10.14807/ijmp.v10i5.896

\begin{tabular}{lll}
\hline 4.1 & 5 & Delivery was made in 3 business days. \\
\hline 4.2 & 4 & There was an error regarding the payment deadline. \\
\hline 4.3 & 5 & No product has been damaged or lost. \\
\hline 5.1 & 5 & Correction of the ticket made on the same day. \\
\hline & Source: Prepared by the authors
\end{tabular}

Table 10: Assignment of the note to the vendor $\mathrm{C}$

\begin{tabular}{|c|c|c|}
\hline Criterion & Note & Note \\
\hline 1.1 & 4 & You had to get in contact twice to get all the information you need. \\
\hline 1.2 & 2 & A proposal valid for 8 days was submitted. \\
\hline 2.1 & 3 & The unit price was $\mathrm{R} \$ 770.00$. \\
\hline 2.2 & 2 & Offered $3 \%$ discount for cash payment. \\
\hline 2.3 & 3 & Offered $5 \%$ discount for purchase of 15 units or more. \\
\hline 2.4 & 5 & Portion up to $5 \mathrm{X}$ without interest. \\
\hline 3.1 & 5 & The product has no history of problems. \\
\hline 3.2 & 5 & The product is original, as indicated by the manufacturer of the equipment. \\
\hline 3.3 & 4 & The validity is 230 days. \\
\hline 4.1 & 4 & Delivery was made in 5 business days. \\
\hline 4.2 & 5 & There was no error as to the conformity between the order and delivery. \\
\hline 4.3 & 5 & No product has been damaged or lost. \\
\hline 5.1 & 5 & $\begin{array}{l}\text { There were no product or delivery issues, and the company also expressed } \\
\text { concern about the quality of the service when it called the lab to see if } \\
\text { everything happened as agreed. }\end{array}$ \\
\hline
\end{tabular}

Source: Prepared by the authors

After evaluating the three suppliers, we performed the calculations to obtain the weighted grade of each subcriterion. The weighting is done using the relative weights of the criteria and subcriteria, and the note $(\mathrm{N})$ that each vendor obtained in the evaluation. The equations used to obtain the grades are presented in Table 11.

Table 11: Equations for the calculation of the weighted grade

\begin{tabular}{|c|c|c|}
\hline $\begin{array}{c}\text { Relative weight of } \\
\text { criteria }\end{array}$ & $\begin{array}{c}\text { Relative weight of } \\
\text { subcriteria }\end{array}$ & $\begin{array}{c}\text { Equation for the calculation of the weighted } \\
\text { grade (Np) }\end{array}$ \\
\hline$W(1)=0.0504$ & $\begin{array}{l}W(1.1)=0.5000 \\
W(1.2)=0.5000\end{array}$ & $\begin{array}{l}\mathrm{Np}(1.1)=\mathrm{W} 1 *(\mathrm{~N} * \mathrm{~W} 1.1) \\
\mathrm{Np}(1.2)=\mathrm{W} 1 *(\mathrm{~N} * \mathrm{~W} 1.2)\end{array}$ \\
\hline$W(2)=0.3935$ & $\begin{array}{l}W(2.1)=0.5408 \\
W(2.2)=0.12 \\
W(2.3)=0.120 \\
W(2.4)=0.0568\end{array}$ & $\begin{array}{l}\mathrm{Np}(2.1)=\mathrm{W} 2 *\left(\mathrm{~N}^{*} \mathrm{~W} 2.1\right) \\
\mathrm{Np}(2.2)=\mathrm{W} 2 *\left(\mathrm{~N}^{*} \mathrm{~W} 2.2\right) \\
\mathrm{Np}(2.3)=\mathrm{W} 2 *\left(\mathrm{~N}^{*} \mathrm{~W} 2.3\right) \\
\mathrm{Np}(2.4)=\mathrm{W} 2 *\left(\mathrm{~N}^{*} \mathrm{~W} 2.4\right)\end{array}$ \\
\hline$W(3)=0.4089$ & $\begin{array}{l}W(3.1)=0.6232 \\
W(3.2)=0.2395 \\
W(3.3)=0.1373\end{array}$ & $\begin{array}{l}\mathrm{Np}(3.1)=\mathrm{W} 3 *\left(\mathrm{~N}^{*} \mathrm{~W} 3.1\right) \\
\mathrm{Np}(3.2)=\mathrm{W} 3 *\left(\mathrm{~N}^{*} \mathrm{~W} 3.2\right) \\
\mathrm{Np}(3.3)=\mathrm{W} 3 *\left(\mathrm{~N}^{*} \text { W3.3) }\right.\end{array}$ \\
\hline$W(4)=0.0900$ & $\begin{array}{l}W(4.1)=0.4000 \\
W(4.2)=0.4000 \\
W(4.3)=0.000\end{array}$ & $\begin{array}{l}\mathrm{Np}(4.1)=\mathrm{W} 4 *\left(\mathrm{~N}^{*} \mathrm{~W} 4.1\right) \\
\mathrm{Np}(4.2)=\mathrm{W} 4 *\left(\mathrm{~N}^{*} \mathrm{~W} 4.2\right) \\
\mathrm{Np}(4.3)=\mathrm{W} 4 *\left(\mathrm{~N}^{*} \mathrm{~W} 4.3\right)\end{array}$ \\
\hline$W(5)=0.0571$ & $W(5.1)=1.0000$ & $\mathrm{~Np}(5.1)=\mathrm{W} 5 *\left(\mathrm{~N}^{*} \mathrm{~W} 5.1\right)$ \\
\hline
\end{tabular}


INDEPENDENT JOURNAL OF MANAGEMENT \& PRODUCTION (IJM\&P)

http://Www.ijmp.jor.br

V. 10, n. 5, September-October 2019

ISSN: 2236-269X

DOI: 10.14807/ijmp.v10i5.896

Table 12 presents the weighted note of the subcriteria for each of the three vendors evaluated.

Table 12: Weighted note of sub-criteria for each vendor

\begin{tabular}{cccc}
\hline Criterion & Vendor A & Vendor B & Vendor C \\
\hline 1.1 & 0.1008 & 0.1008 & 0.1008 \\
\hline 1.2 & 0.1008 & 0.0756 & 0.0504 \\
\hline 2.1 & 0.8514 & 0.8514 & 0.6385 \\
\hline 2.2 & 0,1583 & 0,1583 & 0,1583 \\
\hline 2.3 & 0,1583 & 0,1583 & 0.2375 \\
\hline 2.4 & 0.0671 & 0.0671 & 0.1118 \\
\hline 3.1 & 1,2743 & 1.0194 & 1,2743 \\
\hline 3.2 & 0.3917 & 0.3917 & 0,4897 \\
\hline 3.3 & 0.164 & 0.2246 & 0.2246 \\
\hline 4.1 & 0.1440 & 0.1800 & 0.1440 \\
\hline 4.2 & 0.1440 & 0.1440 & 0.1800 \\
\hline 4.3 & 0.0900 & 0.0900 & 0.0900 \\
\hline 5.1 & 0,1143 & 0.286 & 0.286 \\
\hline TOTAL & $\mathbf{3 , 7 6 3 4}$ & $\mathbf{3 , 7 4 6 9}$ & $\mathbf{3 , 9 8 5 5}$ \\
\hline & $\mathbf{S 0 4}$ &
\end{tabular}

Source: Prepared by the authors

Table 13 presents the final ranking of the AHP algorithm applied to the selection decision of the vendor of a laboratory input, for the case under study, in descending order of punctuation.

Table 13: Final AHP Ranking

\begin{tabular}{cc}
\hline Provider & Global Performance \\
\hline C & 3,9855 \\
\hline A & 3,7634 \\
\hline B & 3,7469 \\
\hline
\end{tabular}

Source: Prepared by the authors

In order to maximize the objective function, it is verified that the vendor $\mathrm{C}$ should be the one selected, since in the evaluation process it was the one that obtained the highest score, as it is represented by Figure 5 . In this sense, it can be concluded that it is the one that meets the needs of the organization, when considering the criteria defined in this model.

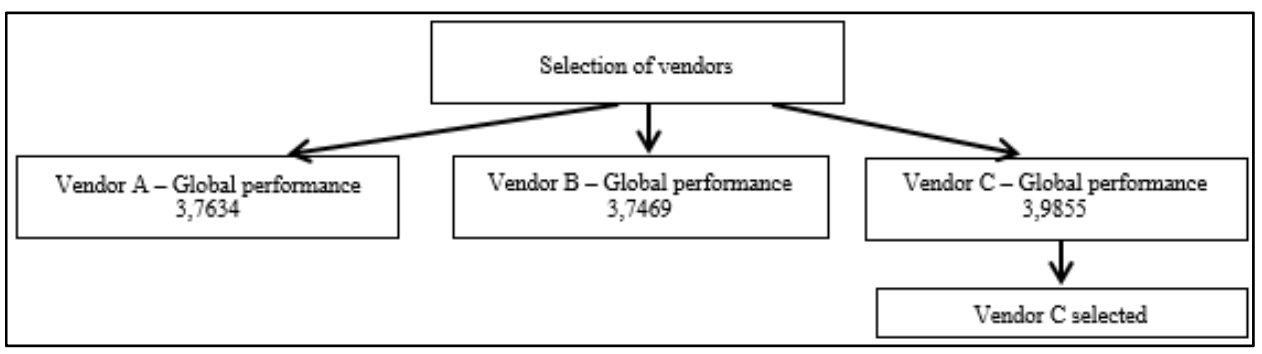

Figure 5: Result of vendor's selection 
INDEPENDENT JOURNAL OF MANAGEMENT \& PRODUCTION (IJM\&P)

http://www.ijmp.jor.br

V. 10, n. 5, September-October 2019

ISSN: 2236-269X

DOI: 10.14807/ijmp.v10i5.896

\section{FINAL CONSIDERATIONS}

The present study had as proposal the elaboration of a decision support model for the selection of a vendor. For this process the AHP method was chosen and it was built to meet the demands of a clinical analysis laboratory. The process of constructing and validating the model was divided into three main stages, with the participation of the laboratory manager, responsible for making decisions in the organization.

The first task of the process was to define the hierarchical structure of the criteria. In a process of constant exchange of information with the decision maker, it was possible to identify the ordering of aspects considered relevant to the decision situation.

In the second moment, a matching comparison between the criteria and subcriteria was made, which allowed to identify the relative preferences between each element considered important in the decision making. Then the calculation was carried out referring to the relative weights of each element of the hierarchy. This process sought to identify the percentage of importance that each criterion represents in the process as a whole. Still in this step, in order to know if the comparisons presented coherence, a consistency analysis of matched comparison matrices

In the final phase of the study, having defined all structure of the AHP model, a purchase simulation was elaborated with three vendors ( $A, B$ and $C$ ) who participated in the quotation processes for the purchase of a laboratory input. This simulation made it possible to interpret that the criteria, "Price" weighing 39.35\% and "Quality" with $40.89 \%$, are the factors that most influence the choice of vendors of the inputs used in the laboratory.

After the simulation was performed, the results of the model were presented to the decision maker, who considered it to be valid and could be used to support the decision in the next purchasing processes to be carried out by the company.

The overall objective of the work was entirely reached, as a multicriteria model was constructed, in order to assist the manager of a clinical analysis laboratory, in decision making related to vendors selection.

Specific objectives were achieved during the development of the study. At first, the criteria and subcriteria were identified, being structured in a hierarchy. Then, through the paired comparisons, the relative weights for each decision element were 
INDEPENDENT JOURNAL OF MANAGEMENT \& PRODUCTION (IJM\&P)

http://Www.ijmp.jor.br

V. 10, n. 5, September-October 2019

ISSN: 2236-269X

DOI: 10.14807/ijmp.v10i5.896

determined. In the last stage of the work, the developed model was tested and presented to the company manager, in order to know if the developed model is effective. This research also contributes to the field of study of statistics, which is central to many other fields.

Regarding the limitations of the work, there is the high degree of commitment of the decision maker during the research and the high demand for time due to the intervention level of the case study.

As a suggestion for future studies, the use of the AHP method is indicated in the development of decision support models directed to different problems, such as those of the research gaps cited in this study, being them: selection of vendors of butchery equipment, uniforms and Construction Materials. Another opportunity would be to develop the same model in another laboratory of clinical analyzes, with the intention of comparing the results, thus making it possible to identify the possible existence of similarities between the two.

\section{REFERENCES}

AIRES, R. F. F.; SILVEIRA NETO, J. C.; SALGADO, C. C. R.; ARAUJO, A. G.; COLOMBO, C. R. (2013) Modelo multicritério de apoio à decisão no processo de seleção de fornecedores. In: XXXIII Encontro Nacional de Engenharia de Produção.

ALENCAR, L. H.; ALMEIDA, A. T. D.; MOTA, C. D. M. (2007) Sistemática proposta para seleção de fornecedores em gestão de projetos. Gestão \& Produção, v. 14, n. 3, p. 477-487.

BALLOU, R. H. (2001) Gerenciamento da cadeia de suprimentos: planejamento, organização e logística empresarial. Porto Alegre: Bookman, 4.

BUSTAMENTE, L. M. G.; DUARTE, R. N.; DE ALMEIDA, D. A. (2010) Proposta de seleção de fornecedores para a indústria de autopeças baseado na aplicação do bocr. In: XXX Encontro Nacional de Engenharia de Produção.

COLETTI, J. A. R.; CASTALLANELLI, C.; FRIES, M. G. M.; DIDONET, S. R. (2002) A importância da gestão de compras para a competitividade das empresas: o caso da Rede Super. In: XXII Encontro Nacional de Engenharia de Produção.

COSTA, R. V.; RAMOS, A. P. (2015) Designing an AHP methodology to prioritize critical elements for product innovation: an intellectual capital perspective. In:

Journal of Business Science and Applied Management, v. 10, n. 1, p. 15-34.

DENICOL, J.; CASSEL, R. A. (2013) Métodos para seleção e avaliação de desempenho de fornecedores na indústria da construção civil: uma revisão sistemática da literatura. In: XXXIII Encontro Nacional de Engenharia de Produção. 
GONÇALO, T. E. E.; DE ALENCAR, L. H. (2011) Seleção de fornecedores para um estaleiro brasileiro utilizando a metodologia ELECTRE III. In: XLIII Simpósio Brasileiro de Pesquisa Operacional.

GUARNIERI, P. (2015) Síntese dos Principais Critérios, Métodos e Subproblemas da Seleção de Fornecedores Multicritério. RAC-Revista de Administração Contemporânea, v. 19, n. 1, p. 1-25.

LONGARAY, A. A.; BUCCO, G. B. (2014) Uso da análise de decisão multicritério em processos licitatórios públicos: um estudo de caso. Revista Produção Online, v. 14, n. 1, p. 219-241.

LONGARAY, A. A.; ENSSLIN, L. (2014) Uso da MCDA na identificação e mensuração da performance dos critérios para a certificação dos hospitais de ensino no âmbito do SUS. Produção, n. 24, p. 41-56.

MAJOR, G. L. A.; BELDERRAIN, M. C. N. (2007) Uma abordagem quantitativa para o problema de seleção de fornecedores. In: XIII Encontro de Iniciação Científica e Pós-Graduação do ITA.

PARK, S.; OK, C.; HA, C. (2018) A stochastic simulation-based holistic evaluation approach with DEA for vendor selection. Computers \& Operations Research, $n$. 100, p. 368-378.

RODRÍGUEZ-ESCOBAR, J.; GONZÁLEZ-BENITO, A. J. (2017) The effect of strategic alignment on purchasing management. Management Research Review, v. 40, n. 11, p. $1175-1200$.

ROESCH, S. M. A. (2010) Projetos de estágio e de pesquisa em administração. São Paulo: Atlas, 3.

SAATY, T. L. (2008) Decision making with the analytic hierarchy process. In: J. Services Sciences, v. 1, n. 1, p. 83-98.

SOUSA, E. P. M.; CARMO, B. B. T. D. (2015) Avaliação de fornecedores de chapa de aço em uma empresa de implementos rodoviários baseada na abordagem multicritério: um estudo de caso. Produção, v. 25, n. 3, p. 611-625.

TRAMARICO, C. L.; SALOMON, V. A. P.; MARINS, F. A. S.; MUNIZ JR, J. (2012) Modelagem com AHP e BOCR para a seleção de prestadores de serviços logísticos. Pesquisa Operacional para o Desenvolvimento, v. 4, n. 2, p. 139-159.

TRIVIÑOS, A. (1995) Introdução à pesquisa em ciências sociais. São Paulo: Atlas.

VIANA, J. C.; ALENCAR, L. H. (2010) Análise do processo de seleção e avaliação de fornecedores em indústrias do setor de alimentos: um estudo de caso múltiplo. In: XXX Encontro Nacional de Engenharia de Produção.

VIANA, J. C.; ALENCAR, L. H. (2012) Metodologias para seleção de fornecedores: uma revisão da literatura. Produção, v. 22, n. 4, p. 625-636.

YIN, R.K. (2001) Estudo de caso: planejamento e métodos. Porto Alegre: Bookmann.

${ }^{\mathrm{i}}$ Full questionnaire is available upon request. 